\title{
PENGARUH E-LEARNING SCHOOLOGY TERHADAP HASIL BELAJAR SIMULASI DIGITAL DENGAN MODEL PEMBELAJARAN SAVI
}

\author{
Komang Sabda Kusumantara1), Gede Saindra Santyadiputra'2), Nyoman Sugihartini ${ }^{3)}$ \\ ${ }^{1}$ Fakultas Teknik dan Kejuruan, Universitas Pendidikan Ganesha \\ email: sabdakusumantara@gmail.com, gsaindras@undiksha.ac.id, sugihartini@undiksha.ac.id
}

\begin{abstract}
Abstrak
Tujuan penelitian ini untuk mengetahui (1) pengaruh media pembelajaran E-learning Schoology terhadap hasil belajar siswa kelas X Administrasi Perkantoran SMK Negeri 1 Singaraja, (2) hasil belajar yang lebih tinggi antara kelompok yang menggunakan media pembelajaran E-learning Schoology dengan kelompok yang menggunakan media pembelejaran konvensional. Jenis penelitian ini adalah eksperimen semu dengan rancangan Post Test Only Control Group Design. Pengumpulan data dilakukan dengan metode tes pilihan ganda untuk mengatur ranah kognitif. Data hasil belajar di analisis melalui uji prasyarat yaitu uji normalitas dan homogenitas dengan hasil kedua kelompok berdistribusi normal dan homogen, dilanjutkan dengan uji hipotesis menggunakan uji-t. Hasil thitung 5,225 yang lebih besar dari tabel 1,994437 menyatakan terdapat perbedaan yang signifikan dalam penggunaan media pembelajaran $E$ learning Schoology dan media pembelajaran konvensional. Kemudian dilihat dari rata-rata hasil belajar, rata-rata kelas eksperimen adalah 19,33 dan kelas control adalah 16,78 dapat disimpulkan bahwa media pembelajaran E-learning Schoology lebih baik dengan rata-rata hasil belajar yang lebih tinggi.
\end{abstract}

Kata kunci: Simulasi Digital, Animasi 2 Dimensi, E-learning, Schoology, hasil belajar.

\section{Abstract}

The purpose of this experimental research are to find out (1) influence E-learning Schoology on student learning outcomes in class X Administrasi Perkantoran SMK Negeri 1 Singaraja, (2) which learning outcomes is higher between groups using E-learning Schoology learning media with groups using conventional media. This type of research is a quasi experiment with Post-test Only Control Group Design. Data collection is doing by multiple choice test method to regulate the cognitive domain. Data of learning outcomes in analysis through prerequisite test that is normality and homogeneity test with result of both group of normal and homogenous distribution, followed by hypothesis test using t-test. Outcome of tcount which 5,061 is higher that tabel which 1,994437 said there is significant influence by using $E$ learning Schoology and conventional media. Then seen from the average learning outcomes, The average of the experimental class is 19.28 and the control class is 16.78 it was concluded that the learning media E-learning Schoology better with average higher learning outcomes.

Keywords : Digital Simulation, 2 Dimentiona Animation, E-learning, Schoology, learning outcome.

\section{PENDAHULUAN}

Menurut Hakim (2005) belajar adalah suatu proses perubahan dari dalam kepribadian manusia dan perubahan tersebut ditampakkan dalam bentuk peningkatan kualitas dan kuantitas tingkah laku seperti peningkatan kecakapan, pengetahuan, sikap, kebiasaan, pemahaman, keterampilan, daya pikir, dan lain-lain. Proses belajar memerlukan suatu media yang dinamakan media pembelajaran.

Menurut Sadiman et.al (2005) media pembelajaran adalah segala sesuatu yang dapat menyalurkan pesan, dapat merangsang fikiran, perasaan, dan kemauan peserta didik sehingga dapat mendorong terciptanya proses belajar pada diri peserta didik. Tanpa media, komunikasi tidak akan terjadi dan proses 
pembelajaran sebagai proses komunikasi juga tidak akan bisa berlangsung secara optimal. Penggunaan media pembelajaran secara tepat, dan bervariasi dapat mengatasi sikap pasif anak didik.

SMK Negeri 1 Singaraja merupakan satu dari sekian SMK di Kabupaten Buleleng yang telah menggunakan kurikulum 2013. Pada semua paket keahlian terdapat mata pelajaran Simulasi. Berdasarkan standar isi mata pelajaran SMK yang menekankan pada kemandirian siswa dan pemberian pengalaman belajar langsung, maka dalam pembelajaran simulasi digital diperlukan sebuah media yang dapat mendukung aktivitas siswa dalam mempelajari simulasi digital sehingga dapat belajar mandiri tanpa harus bergantung pada guru mata pelajaran dalam mengembangkan bakat dan potensi yang dimiliki.

Menurut hasil observasi dan wawancara pada guru dan siswa kelas $X$ A Administrasi Perkantoran, kelas X B Administrasi Perkantoran, dan kelas $\mathrm{X} C$ Administrasi Perkantoran ditemukan beberapa kendala. Adapun kendala yang sering terjadi dalam pembelajaran Simulasi Digital di antaranya: 1) siswa bosan terhadap media pembejajaran yang digunakan oleh guru, 2) siswa menginginkan guru menggunakan media pembelajaran yang lebih bervariasi, 3) siswa menyatakan bahwa dengan menggunakan media pembelajaran sangat berpengaruh terhadap motivasi dan hasil belajar siswa, dan 4) sebanyak 80 siswa dari 112 siswa masih mendapatkan nilai dibawah Kriteria Ketuntasan Minimal (KKM) yaitu $75,00,5)$ siswa tidak dapat berinteraksi langsung dengan media pembelajaran. Guru harus memiliki kompetensi untuk mengembangkan pembelajaran. Berbagai model pembelajaran yang memadukan teknologi berbasis web pun mulai dikembangkan seperti pembelajaran dengan e-learning, e-modul ataupun blanded learning (Sugihartini \& Agustini, 2017). Salah satu menggunakan media pembelajaran alternatif adalah penggunaan e-learning.
Menurut Ahmadi (2012) e-learning adalah sistem atau konsep pendidikan yang memanfaatkan teknologi informasi dalam proses belajar mengajar. Terdapat banyak fasilitas situs pendidikan yang menyediakan wadah pembelajaran yang sesuai dengan kemampuan siswa, salah satunya adalah Schoology. Diani (2015) mengungkapkan bahwa Schoology merupakan salah satu Learning Management System (LMS) berbentuk web sosial yang menawarkan pembelajaran seperti di dalam kelas secara gratis dan mudah digunakan Facebook. Schoology memiliki layanan berupa catatan kehadiran, tes dan kuis, pekerjaan rumah, serta Schoology di sediakan dalam bentuk aplikasi telepon seluler dengan akses internet (Apriyana, 2015). Aminoto (2014) menyatakan bahwa membangun e-learning dengan Schoology juga lebih menguntungkan bila dibanding menggunakan moodle yaitu karena tidak memerlukan hosting dan pengelolaan Schoology lebih user friendly.

Ariawan (2014) menyatakan bahwa model pembelajaran SAVI memberikan siswa teknik belajar inovatif yaitu dengan berlatih langsung, mendengarkan, melihat dan memahami isi materi pelajaran. Kelebihan model pembelajaran SAVI adalah dengan melibatkan fungsi indera untuk belajar tentu siswa akan lebih paham terhadap materi pelajaran. Pemahaman materi yang lebih baik, akan meningkatkan kemampuan intelektual siswa sehingga bisa mencapai kompetensi inti yang ditentukan. Sejalan dengan penelitian ini, Ariawan (2014) juga mengembangkan modul ajar Animasi 2 Dimensi dengan model pembelajaran SAVI yang menyatakan bahwa berdasarkan analisis yang dilakukan didapatkan persentase total respon siswa sebesar $86,59 \%$ sehingga jika dikonversikan kedalam kriteria penilaian persentase tersebut berada dalam kualifikasi baik.

Berdasarkan uraian tersebut, maka penulis tertarik untuk mencoba menerapkan media pembelajaran $e$ learning Schoology pada mata pelajaran 
Simulasi Digital di SMK Negeri 1 Singaraja menggunakan model pembelajaran SAVI (Somatis, Auditori, Visual, Dan Intelektual) dengan melaksanakan penelitian yang berjudul "Pengaruh Penerapan E-learning Schoology Pokok Bahasan Animasi 2 Terhadap Hasil Belajar Simulasi Digital Dengan Model Pembelajaran Savi (Somatis, Auditori, Visual, Dan Intelektual) Di Kelas X Administrasi Perkantoran Smk Negeri 1 Singaraja".

\section{METODE}

Penelitian ini merupakan penelitian Eksperimen. Mengingat tidak semua variabel atau gejala yang muncul dan kondisi eksperimen dapat diatur dan dikontrol secara ketat, maka penlelitian ini dikategorikan penelitian eksperimen semua (quasi experiment) (Sugiyono, 2014).

Standar kompetensi yang digunakan dalam penelitian ini yaitu "Animasi 2 Dimensi". Populasi penelitian ini adalah seluruh siswa kelas $X$ Administrasi Perkantoran di SMK Negeri 1 Singarja Tahun Ajaran 2016/2017 dan sampel penelitian ini yaitu kelas $X$ Administrasi Perkantoran $B$ sebagai kelas eksperimen sebanyak 36 siswa, X Administrasi Perkantoran C sebagai kelas kontrol sebanyak 36 siswa. Pada penelitian ini diberikan perlakuan yang berbeda terhadap kedua kelas sampel. Kelas eksperimen diberikan perlakuan berupa penerapan media pembelajaran E-learning Schoology dengan menggunakan model pembelajaran SAVI (Somatis, Auditori, Visual dan Intelektual) dan kelas kontrol diberikan perlakuan berupa penerapan media pembelajaran konvensional.

Desain penelitian yang digunakan adalah posttest only control group design. Rancangan ini dipilih karena selama melakukan eksperimen tidak memungkinkan mengubah kelas yang sudah ada. Terdapat 2 variabel dalam penelitian ini yaitu variabel bebas dan variabel terikat. Variabel bebas terdiri dari media pembelajaran E-learning Schoology serta veriabel terikat adalah hasil belajar.
Metode pengumpulan data yang digunakan pada penelitian ini adalah metode tes dengan menggunakan instrumen objektif berupa soal pilihan ganda dengan 5 pilihan jawaban. Sebelum menentukan soal-soal yang digunakan, terlebih dahulu dilakukan uji Validitas Isi dengan menggunakan formula Gregory dengan rumus sebagai berikut.

$$
\text { Validitas Isi }=\frac{D}{A+B+C+D}
$$

Keterangan:

$$
\begin{aligned}
& \text { A } \quad \begin{array}{c}
\text { k sel yang menunjukkan } \\
\text { ketidaksetujuan antara kedua } \\
\text { penilai }
\end{array} \\
& \text { B dan } \mathrm{C}=\text { sel yang menunjukkan } \\
& \text { perbedaan pandangan antara } \\
& \text { penilai } \\
& \text { D sel yang menunjukkan } \\
& \text { persetujuan yang valid }
\end{aligned}
$$

Setelah dilakukan uji validitas isi oleh dua judges, didaptkan nilai 1,00 yang tergolong Sangat Tinggi. Maka, langkah selanjutnya yang dilakukan adalah uji Validitas Konstruk dengan rumus sebagai berikut.

$$
\mathrm{Y}_{\mathrm{pbi}}=\frac{M_{p}-M_{t}}{s_{t}} \sqrt{\frac{p}{q}}
$$

Keterangan:

$\mathrm{Y}_{\mathrm{pbi}}=$ Validitas butir soals

$\mathrm{M}_{\mathrm{p}}=$ Rerata skor total dari subyek yang menjawab betul butir yang dicari validitasnya

$\mathrm{M}_{\mathrm{t}}=$ Rerata skor total

$\mathrm{S}_{\mathrm{t}}=$ Standar deviasi skor total

$\mathrm{p}=$ Proporsi siswa yang menjawab benar butir yang dicari validitasnya

$\mathrm{q}=$ Proporsi siswa yang menjawab salah butir yang dicari validitasnya $\mathrm{q}=1-$ p)

Dari uji coba validitas yang dilakukan pada 50 responden, didapat 37 butir soal yang valid. Selanjutnya adalah uji Reliabilitas dengan rumus sebagai berikut.

$$
\mathrm{r}_{11}=\left(\frac{n}{n-1}\right)\left(\frac{s_{t}^{n}-n \overline{p q}}{s_{t}^{n}}\right)
$$


Keterangan:

$$
\begin{array}{ll}
\mathrm{r}_{11} & =\text { Reliabilitas soal } \\
\mathrm{S}_{\mathrm{t}} & =\text { Standar deviasi skor total } \\
\mathrm{n} & =\text { Banyak butir } \\
\bar{p} & =\text { Proporsi rata-rata siswa yang } \\
& \text { menjawab benar untuk semua butir } \\
\bar{q} & =\text { Proporsi rata-rata siswa yang } \\
& \text { menjawab salah untuk semua butir }
\end{array}
$$

Berdasarkan hasil analisis reliabilitas tes hasil belajar Simulasi Digital siswa dengan menggunakan rumus KR20, didapatkan angka reliabilitas sebesar $r_{11}=$ 0,883 dengan butir item soal sebanyak 37 dan berkualifikasi sangat tinggi. Jadi instrumen tersebut layak dan dapat dipercaya untuk digunakan sebagai alat pengumpulan data. Selanjutnya adalah uji Indeks Daya Beda dengan rumus sebagai berikut.

$$
\mathrm{DB}=\frac{B a}{J a}-\frac{B b}{J b}
$$

\section{Keterangan:}

$$
\begin{array}{ll}
\mathrm{DB} & =\text { Indeks daya beda tes } \\
\mathrm{Ba} & =\text { banyak kelompok atas yang } \\
& \text { menjawab butir dengan benar } \\
\mathrm{Ja} & =\text { banyak peserta kelompok atas } \\
\mathrm{Bb} & =\text { banyak kelompok bawah yang } \\
& \text { menjawab butir dengan benar } \\
\mathrm{Jb} & =\text { banyak peserta kelompok bawah }
\end{array}
$$

Berdasarkan hasil analisis diperoleh sebanyak 17 butir tes termasuk kategori baik, 16 butir tes termasuk kategori cukup, 4 butir soal termasuk kategori lemah dan tidak ada soal yang memiliki kategori sangat baik serta tidak diterima. Langkah selanjutnya adalah menghitung uji Kesukaran Butir dengan rumus sebagai berikut.

$$
\mathrm{I}=\frac{B}{I S}
$$

Keterangan:

$\mathrm{I}=$ Indeks Kesukaran Butir

B = Banyaknya siswa yang

JS = Jumlah siswa yang mengikuti tes
Berdasarkan hasil uji tingkat kesukaran tes diketahui 37 soal tergolong kategori sedang dan tidak ada soal yang terlalu mudah atau terlalu sukar dan uji Efektivitas Pengecoh. Kriteria pengecoh yang baik adalah apabila pengecoh tersebut dipilih oleh paling sedikit 5\% dari peserta tes. Berdasarkan hasil uji keefektifan pengecoh dari 37 butir soal, diketahui 29 butir soal memiliki pengecoh yang efektif dan 8 butir soal memiliki pengecoh yang tidak efektif.

Uraian singkat tentang teknik analisis data yang digunakan pada penelitian ini adalah sebagai berikut.

1. Teknik Analisis Deskriptif

Rumus yang digunakan untuk menghitung rata-rata, varians dan standar deviasi adalah sebagai berikut.

a. Rata-Rata

$$
\bar{X}=\frac{\sum f_{i} x_{i}}{f_{i}}
$$

Keterangan:

$$
\begin{aligned}
& \bar{X}=\text { rata }- \text { rata } \\
& f_{i}=\text { jumlah_frekuensi } \\
& x_{i}=\text { nilai_tengah }
\end{aligned}
$$

b. Varians

$$
s^{2}=\sum \frac{f_{i}\left(x_{i}-x\right)^{2}}{n-1}
$$

Keterangan:

$$
\begin{aligned}
& s^{2}=\text { varians } \\
& f_{i}=\text { frekuensi } \\
& x_{i}=\text { nilai_tengah } \\
& x=\text { rata }- \text { rata } \\
& n=\text { jumlah_siswa }
\end{aligned}
$$

C. Standar Deviasi

$$
s=\sqrt{s^{2}}
$$

\footnotetext{
Keterangan:

$s=s \tan$ dar_deviasi

$s^{2}=$ varians
} 
Data skor post-test kemudian dikategorikan sesuai dengan pedoman berikut.

Tabel 1 Kriteria Skor Posttest

\begin{tabular}{ccc}
\hline Rentangan Data & Skala & Kualifikasi \\
\cline { 1 - 2 }$M_{i}+1,5 S D_{i}<X \leq M_{i}+3,0 S D_{i}$ & 4 & Sangat Tinggi \\
\cline { 1 - 2 }$M_{i}+0,5 S D_{i}<X \leq M_{i}+1,5 S D_{i}$ & 3 & Tinggi \\
\hline$M_{i}-0,5 S D_{i}<X \leq M_{i}+0,5 S D_{i}$ & 2 & Sedang \\
\hline$M_{i}-1,5 S D_{i}<X \leq M_{i}-0,5 S D_{i}$ & 1 & Rendah \\
\hline$M_{i}-3,0 S D_{i}<X \leq M_{i}-1,5 S D_{i}$ & 0 & Sangat Rendah \\
\hline
\end{tabular}

2. Teknik Analisis Uji Asumsi

Data hasil penelitian dianalisis dengan uji-t. Asumsi yang harus dipenuhi dalam uji-t meliputi (1) data berdistribusi normal dan (2) varians dalam kelompok homogen. Sebelum dianalisis, terlebih dahulu dilakukan uji asumsi. Pengujian asumsi dilakukan untuk mengetahui apakah data yang tersedia dapat dianalisis dengan statistik parametrik atau tidak. Terkait dengan statistik yang digunakan untuk analisis data dalam penelitian ini, maka uji asumsi yang dilakukan adalah uji normalistas dan uji homogenitas dengan menggunakan SPSS 20.0 dengan angka signifikan yang lebih besar dari 0,05. Selain menggunakan SPSS 20.0, perhitungan uji normalitas juga dapat dilakukan dengan menggunakan Ms. Excel 2010 dengan rumus Chi Kuadrat. Uji homogenitas data juga dapat dilakukan dengan menggunakan Ms. Excel 2010 dengan menggunakan rumus sebagai berikut.

$$
F=\frac{\text { VariansTerbesar }}{\text { VariansTerkecil }}
$$

\section{Uji Hipotesis}

Hipotesis yang diuji pada penelitian ini adalah sebai berikut.

$\mathrm{H}_{0}=$ Tidak terdapat perbedaan hasil belajar Simulasi Digital yang signifikan antara kelompok siswa yang dibelajarkan tanpa menggunakan media pembelajaran
E-learning Schoology dan siswa yang dibelajarkan menggunakan media pembelajaran E-learning Schoology. $\mathrm{H}_{0}:\left[\mu_{\times 1} \mathrm{Y}\right]=\left[\mu_{\mathrm{x} 2} \mathrm{Y}\right]$, melawan

$\mathrm{H}_{1}=$ Terdapat perbedaan hasil belajar Simulasi Digital yang signifikan antara kelompok siswa yang dibelajarkan dengan menggunakan media pembelajaran E-learning Schoology dan siswa yang dibelajarkan tanpa menggunakan media pembelajaran E-learning Schoology.

$\mathrm{H}_{1}:\left[\mu_{\times 1} \mathrm{Y}\right] \neq\left[\mu_{\times 2} \mathrm{Y}\right]$.

Untuk meguji hipotesis dengan menggunakan uji-t. Uji ini digunakan untuk menguji hasil posttest kelompok eksperimen dan kelompok kontrol. Uji-t untuk sampel yang tidak berkorelasi atau terpisah terdiri dari dua jenis rumus, yaitu separated varians dan polled varians.

Rumus Separated Varians:

$$
\mathrm{t}=\frac{x_{1}-x_{2}}{\sqrt{\frac{S_{1}^{n}}{n_{1}}+\frac{s_{2}^{n}}{n_{2}}}}
$$

Rumus Polled Varians:

$$
\mathrm{t}=\frac{x_{1}-X_{2}}{\sqrt{\frac{\left(n_{1}-1\right) s_{1}^{2}+\left(n_{2}-1\right)_{2}^{\frac{z}{2}}}{n_{1}+n_{2}-2}\left(\frac{1}{n_{1}}+\frac{1}{n_{2}}\right)}}
$$

Keterangan:

$\mathrm{t}=$ uji hipotesis

$\mathrm{X}_{1}=$ rata-rata kelompok eksperimen

$\mathrm{X}_{2}=$ rata-rata kelompok kontrol

$\mathrm{n}_{1}=$ jumlah responden klp eksperimen 
$\mathrm{n}_{2}=$ jumlah responden kelompok kontrol

$\mathrm{s}_{1}{ }^{2}=$ varians kelompok eksperimen

$\mathrm{s}_{2}{ }^{2}=$ varians kelompok kontrol

Ketentuan pemilihan t-test yang akan digunakan dalam pengujian hipotesis adalah sebagai berikiut :

1. Bila jumlah anggota sampel $n 1=n 2$ dan varians homogen, maka dapat digunakan rumus t-test, baik yang separated varians maupun polled varians. Untuk mengetahui t-test Tabel digunakan $\mathrm{db}=(\mathrm{n} 1+\mathrm{n} 2)-2$.

2. Bila $\mathrm{n} 1 \neq \mathrm{n} 2$, varians homogen dapat digunakan t-test dengan polled varians. Besarnya $\mathrm{dk}=(\mathrm{n} 1+\mathrm{n} 2)-2$.

3. Bila $n 1=n 2$, varians tidak homogen dapat digunakan salah satu rumus diatas, dengan $\mathrm{db}=\mathrm{n} 1-1$ atau $\mathrm{db}=\mathrm{n} 2$ $-1$.

4. Bila $\mathrm{n} 1 \neq \mathrm{n} 2$ dan varians tidak homogen. Untuk ini digunakan rumus separatef varians. Harga $t$ sebagai pengganti harga tabel dihitung dari selisihi harga tabel dengan $\mathrm{db}=\mathrm{n} 1-1$ dan $\mathrm{db}=\mathrm{n} 2-1$, dibagi dua dan kemudian ditambah dengan harga tabel terkecil.

Untuk mendapatkan hasil yang lebih akurat analisis uji-t dilakukan dengan dua cara, yaitu secara manual dan dengan bantuan program SPSS PC 20.0 for Windows. Apabila cara manual untuk menghasilkan interpretasi, maka thitung tersebut harus dikomparasikan dengan $t_{\text {Tabel }}$ dengan indikator taraf signifikan 5\% $(0,05)$. Apabila thitung lebih besar daripada $t_{\text {Tabel }}$ (thitung $>t_{\text {Tabel }}$ ), maka terdapat perbedaan yang signifikan antara kedua variabel atau sampel. Sedangkan apabila $t_{\text {hitung }}$ lebih kecil dari $t_{\text {Tabel }}\left(t_{\text {hiung }}<t_{\text {Tabel }}\right.$ ), maka tidak terdapat perbedaan yang signifikan antara kedua variabel atau sampel. Sedangkan hasil interpretasi output program SPSS PC 20.0 for Windows dilakukan dengan melihat nilai signifikansi. Angka signifikansi lebih kecil dari 0,05 berarti $\mathrm{H}_{0}$ ditolak dan artinya terdapat perbedaan variabel bebas antar kelompok menurut sumber.
Penelitian eksperimen ini bertujuan untuk mencari pengaruh penerapan $E$ learning Schoology terhadap hasil belajar Simulasi Digital siswa kelas X Administrasi Perkantoran. Setelah diberi perlakuan pada kelas eksperimen diberikan tes akhir, begitu pula pada kelas kontrol. Dari hasil data skor post-test, didapatkan bahwa nilai rata-rata kelas eksperimen yang menggunakan media E-learning Schoology adalah 19,33 dengan varians 4,18 dan standar deviasi sebesar 2,04 dengan distribusi nilai seperti pada Gambar 1 berikut.

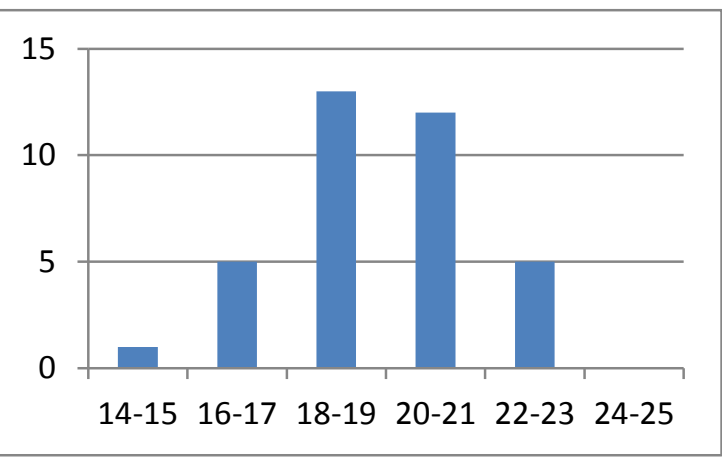

Gambar 1 Grafik Hasil Post-test Kelompok Eksperimen

Histrogram pada Gambar 1 dapat dijelaskan sebagai berikut. Sebanyak 1 siswa $(2,78 \%)$ memiliki skor antara $14-15$, sebanyak 5 siswa $(13,89 \%)$ memiliki skor antara 16-17, sebanyak 13 siswa $(36,11 \%)$ memiliki skor antara 18-19, sebanyak 12 siswa $(33,33 \%)$ memiliki skor antara $20-21$, sebanyak 5 siswa $(13,89 \%)$ memiliki skor antara 22-23, dan tidak ada siswa yang mendapatkan skor antara 2425.

Sedangkan kelas kontrol mendapatkan rata-rata 16,78 dengan varians sebesar 4,61 dan standar deviasi sebesar 2,15 dengan distribusi nilai seperti pada Gambar 2 berikut.

\section{HASIL DAN PEMBAHASAN}




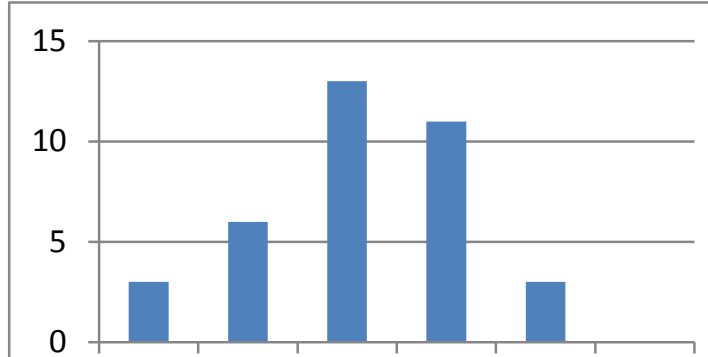

$\begin{array}{llllll}12 .-13 & 14-15 & 16-17 & 18-19 & 20-21 & 22-23\end{array}$

Gambar 2 Grafik Hasil Post-test Kelompok Kontrol

Histrogram pada Gambar 2 Histogram Hasil Belajar Simulasi Digital Kelompok Kontrol dapat dijelaskan sebagai berikut. Sebanyak 3 siswa $(8,33 \%)$ memiliki skor antara 12-13, sebanyak 6 siswa $(16,67 \%)$ memiliki skor antara 14-15, sebanyak 13 siswa $(36,11 \%)$ memiliki skor antara 16-17, sebanyak 11 siswa $(30,56 \%)$ memiliki skor antara $18-19$, sebanyak 3 siswa $(8,33 \%)$ memiliki skor antara 20-21, dan tidak ada siswa yang mendapatkan skor 22-23.

Berdasarkan distribusi nilai pada kelas eksperimen, maka kategori nilai pada kelas eksperimen dapat dikelompokkan sesuai dengan kategori pada Gambar 3 berikut.

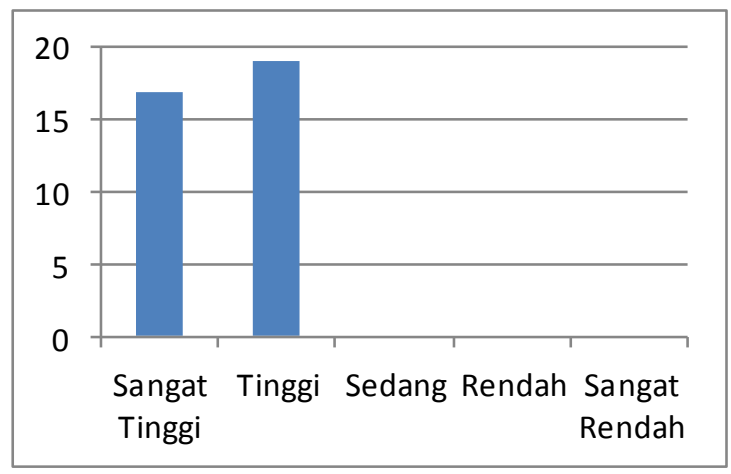

Gambar 3 Kategori Skor Post-test Kelas Eksperimen

Pada Gambar 3 dapat diketahui bahwa hasil belajar Simulasi Digital siswa kelompok eksperimen sebanyak 17 siswa $(47,22 \%)$ berkategori sangat tinggi, sebanyak 19 siswa (52,78\%) berkategori tinggi, serta tidak ada siswa yang memiliki hasil belajar Simulasi Digital berkategori sedang, rendah, dan sangat rendah.
Sedangkan untuk kelas kontrol dapat dilihat pada Gambar 4 berikut.

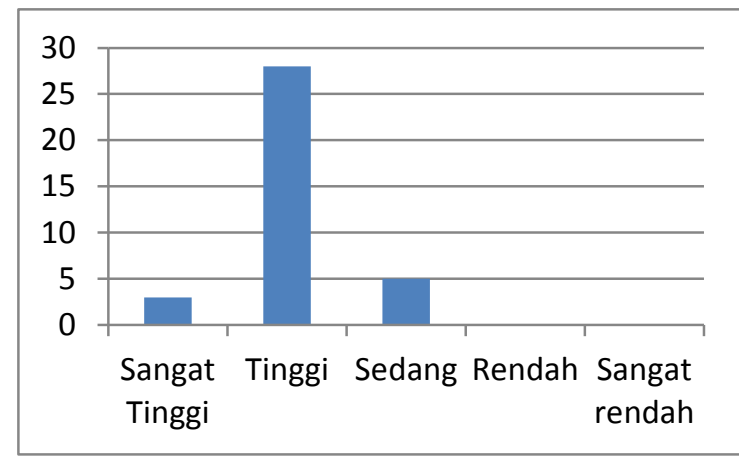

\section{Gambar 4 Kategori Skor Post-test Kelas} Kontrol

Pada Gambar 4 dapat diketahui bahwa hasil belajar Simulasi Digital siswa kelompok kontrol sebanyak 3 siswa $(8,33 \%)$ berkategori sangat tinggi, sebanyak 28 siswa $(77,78 \%)$ berkategori tinggi, sebanyak 5 siswa $(13,89 \%)$ serta tidak ada siswa yang memiliki hasil belajar Simulasi Digital berkategori rendah, dan sangat rendah.

Data skor post-test kedua kelompok tersebut kemudian dilakukan uji normalitas dengan menggunakan SPSS 20.0. Hasil uji normalitas menggunakan SPSS 20.0 untuk kelas eksperimen adalah sebesar 0,184 yang menyatakan bahwa data kelas eksperimen berdistribusi normal. Uji normalitas kelas eksperimen dengan menggunakan Ms. Excel 2010 mendapatkan nilai $X^{2}$ hitung sebesar 0,77 . $X^{2}$ tabel untuk $d b=5$ adalah 11,070 . Karena $X^{2}$ hitung lebih kecil dari $X^{2}$ tabel maka dapat dinnyatakan bahwa data skor post-test kelas eksperimen berdistribusi normal.

Hasil uji normalitas menggunakan SPSS 20.0 untuk kelas kontrol adalah sebesar 0,159 yang menyatakan bahwa data kelas kontrol berdistribusi normal. Uji normalitas kelas eksperimen dengan menggunakan Ms. Excel 2010 mendapatkan nilai $X^{2}$ hitung sebesar 1,48 . $X^{2}$ tabel untuk $d b=5$ adalah 11,070 . Karena $X^{2}$ hitung lebih kecil dari $X^{2}$ tabel maka dapat dinnyatakan bahwa data skor post-test kelas kontrol berdistribusi normal. 
Selanjutnya adalah melakukan uji homogenitas pada kedua kelas tersebut dengan menggunakan SPSS 20.0. Hasil uji homogenitas yang didapatkan adalah 0,718 yang menyatakan bahwa data kedua kelas tersebut adalah homogen. Uji homogenitas dengan Ms. Excel 2010 menggunakan uji $F$ mendapatkan $f_{\text {hitung }}$ sebesar 1,161 . $F_{\text {tabel }}$ dengan $\mathrm{db}=35$ adalah 1,757. Karena $f_{\text {hitung }}$ lebih kecil dari $f_{\text {tabel }}$ maka hal ini berarti bahwa varians data hasil belajar Simulasi Digital antara kelompok eksperimen dan kelompok kontrol adalah sama atau homogen.

Setelah memenuhi uji prasyarat tersebut, maka uji hipotesis bisa dilakukan. Uji hipotesis menggunakan uji hipotesis adalah uji-t. Sesuai dengan hipotesis penelitian atau hipotesis alternatif $\left(H_{1}\right)$ yang telah diajukan pada kajian teori, maka dapat dirumuskan hipotesis untuk mengetahui apakah terdapat perbedaan yang signifikan atau tidak terhadap siswa yang menggunakan media pembelajaran E-learning Schoology dengan siswa yang menggunakan media pembelajaran konvensional.

Uji hipotesis yang digunakan adalah uji-t dengan menggunakan rumus Separated Varians. Hasil uji-t menggunakan rumus Separated Varians mendapatkan thitung sebesar 5,225. Nilai $t_{\text {tabel }}$ dengan $\mathrm{db}=70$ adalah 1,994437. Jika dibandingkan antara $t_{\text {hitung }}$ dan $t_{\text {tabel }}$ maka thitung dinyatakan lebih besar dari $t_{\text {tabel }}$ sehingga dapat dikatakan bahwa terdapat perbedaan yang signifikan antara kelompok siswa yang menggunakan media E-learning Schoology dengan siswa yang menggunakan media konvensional. Uji-t juga dapat dilakukan pada SPSS 20.0. Berdasarkan hasil perhitungan posttest kelompok eksperimen dan kelompok kontrol dengan menggunakan SPSS 20.0, dari output analisis menunjukan nilai Sig. adalah 0,000. Oleh karena nilai probabilitas siginifikan $<0,05$, maka $\mathrm{H}_{0}$ ditolak atau $\mathrm{H}_{1}$ diterima. Sehingga dapat dikatakan bahwa terdapat perbedaan yang signifikan penggunaan media pembelajaran E-learning Schoology.
Hasil belajar kelas eksperimen yang menggunakan media pembelajaran $E$ learning Schoology pada pokok bahasan Animasi 2 Dimensi lebih baik, dilihat dari nilai rata-rata skor siswa kelompok eksperimen lebih tinggi dibandingkan kelompok kontrol $(19,33>16,78)$. Hal ini juga didukung toeri yang disampaikan oleh Wicaksono (2015) yang mengatakan bahwa e-learning merupakan sebuah pendekatan terhadap pembelajaran yang mampu meningkatkan hasil belajar. Hasil belajar kelas eksperimen yang dibelajarkan dengan media pembelajaran Schoology lebih tinggi dibandingkan dengan kelas kontrol yang dibelajarkan dengan media pembelajaran powerpoint disebabkan karena siswa tidak hanya sebatas mendengar apa yang diberikan oleh guru melainkan siswa turut aktif dalam proses pembelajaran yang dimana hal ini merupakan bagian dari kegunaan media pembelajaran (Sadiman et.al, 2005).

Hasil penelitian ini berbeda signifikan terhadap hasil belajar Simulasi Digital siswa kelas $\mathrm{X}$ Administrasi Perkantoran sejalan dengan beberapa penelitian yang juga memiliki perbedaan yang signifikan terhadap penerapan E-learning Schoology diantaranya: 1) Diani (2015) yang menyatakan bahwa pelajaran matematika dengan berbantuan E-learning Schoology memiliki hasil yang lebih baik dibandingkan dengan menggunakan media alat peraga papan kuadran trigonometri. Hal ini dikarenakan siswa tidak jenuh dan bisa focus terhadap materi pelajaran. Selain itu ketika mengalami kesulitan siswa menanyakan peneliti di luar jam pelajaran baik secara privacy maupun tidak di dalam Schoology, 2) Ramhaningrum (2016) mengatakan bahwa terdapat pengaruh yang signifikan terhadap penerapan media pembelajaran E-learning Edmodo terhadap hasil belajar siswa dengan siswa yang diberikan dengan model pembelajaran langsung yang ditunjukkan dengan angka signifikansi 0,001 yang lebih kecil dibandingkan dengan taraf signifikan 0,05, 3) Irawan (2017) mengatakan bahwa terdapat perbedaan yang signifikan 
terdahap hasil belajar siswa yang belajar dengan mengkombinasikan pelajaran tatap muka berbasis Schoology dibandingkan dengan siswa yang belajar dengan model pembelajaran ProblemBased Learning. Hal ini dikarenakan siswa mampu untuk meningkatkan kegiatan pembelajaran diluar jam pelajaran dan mampu untuk mencari materi secara individu dengan menggunakan laptop, komputer maupun smartphone yang dimiliki.

\section{SIMPULAN DAN SARAN}

Berdasarkan paparan hasil penelitian dan pembahasan dapat disimpulkan sebagai berikut: 1) Adanya perbedaan yang signifikan penggunaan media pembelajaran E-learning Schoology dan media pembelajaran konvensional. Hal ini dapat dilihat dari hasil perhitungan uji-t ditemukan $t_{\text {hitung }}=5,061$ yang selanjutnya dibandingkan dengan tabel dan taraf signifikansi 5\% sebesar 1,994437 karena $F_{\text {hitung }}>\mathrm{F}_{\text {tabel }}$ maka $\mathrm{H}_{0}$ ditolak atau $\mathrm{H}_{1}$ diterima., 2) Dilihat rerata hasil belajar kelompok eksperimen adalah 19,33, sedangkan rata-rata posttest untuk kelompok kontrol sebesar 16,78. Berdasarkan rata-rata hasil belajar tersebut maka dapat disimpulkan bahwa hasil belajar lebih tinggi terdapat pada siswa yang yang menggunakan media pembelajaran E-learning Schoology dibandingkan media pembelajaran konvensional, 3) Hasil belajar kelas eksperimen yang dibelajarkan dengan media pembelajaran Schoology lebih tinggi dibandingkan dengan kelas kontrol yang dibelajarkan dengan media pembelajaran konvensional disebabkan karena siswa tidak hanya sebatas mendengar apa yang diberikan oleh guru melainkan siswa turut aktif dalam proses pembelajaran yang dimana hal ini merupakan bagian dari karakteristik dari $e$ learning.

\footnotetext{
Berdasarkan hasil penelitian dapat diajukan beberapa saran guna meningkatkan kualitas pembelajaran Simulasi Digital yaitu sebagai berikut: 1) Hasil penelitian ini menunjukkan bahwa
}

siswa yang belajar dengan menggunakan media pembelajaran E-learning Schoology secara signifikan memperoleh hasil belajar Simulasi Digital yang lebih baik daripada siswa yang menggunakan media pembelajaran konvensional. Oleh karena itu, penulis menyarankan kepada guru pengajar untuk menerapkan media pembelajaran E-learning Schoology pada proses pembelajaran selanjutnya, 2) Pada penelitian sebelumnya mengenai pengembangan media ajar Animasi 2 Dimensi pada kelas X SMK Negeri 1 Singaraja menyebutkan bahwa media ajar tersebut mendapatkan respon sangat positif dari siswa. Pada penelitian eksperimen ini diketahui bahwa media pembelajaran Schoology dengan materi Animasi 2 Dimensi berbeda signifikan terhadap hasil belajar siswa. Diharapkan pada peneliti selanjutnya bisa menerapkan media pembelajaran ini dengan penelitian tindakan kelas untuk meningkatkan mutu pembelajaran di kelas.

\section{DAFTAR PUSTAKA}

Ahmadi, I. K. (2012). Mengembangkan Pendidikan Berbasis Keunggulan Lokal Dalam KTSP. Jakarta: PT. Prestasi Pustakaraya.

Aminoto, T. (2014). Penerapan Media Elearning Berbasis Schoology Untuk Meningkatkan Aktivitas dan Hasil Belajar Materi Usaha dan Energi Di Kelas XI SMA N 10 Kota Jambi.

Apriyana, K. F. (2015). Pengembangan Portal E-learning Berbasis Schoology Pada Mata Pelajaran IPS Kelas VIII di SMPN 1 Banjarangkan.

Ariawan, I. G. (2014). Pengembangan Modul Ajar Simulasi Digital Pokok Bahasan Animasi 2 Dimensi dengan Model Pembelajaran SAVI untuk Siswa Kelas $X$ SMK Negeri 1 Singaraja. 382-388.

$\begin{array}{ccr}\text { Diani, T. R. } & \text { (2015). } & \text { Pengaruh } \\ \text { Pembelajaran } & \text { Berbantu } & \text { E-learning } \\ \text { Schoology } & \text { Pada } & \text { Materi } \\ \text { Perbandingan } & \text { Trigonometri } & \text { Kelas X } \\ \text { TPMI SMK Ma'arif } 4 \text { Kebumen Tahun } \\ \text { Pelajaran 2014/2015. 163-168. }\end{array}$


Sadiman, A., Raharjo, R., Haryono, A., \& Rahardjito. (2005). Media Pendidikan. Jakarta: PT. Raja Grafindo Persada.

Sugihartini, N., \& Agustini, K. (2017). Asesmen Otentik sebagai Pendukung Desain Instruksional Jaringan Komputer Berstrategi BlendedLearning dengan Pendekatan Konstruktivistik. Journal of Education Action Research, 82-90.

Sugiyono. (2014). Metode Penelitian Pendidikan. Bandung: Alfabeta.

Wicaksono, S. (2016). Computer Supported Collaborative Learning. Malang: Seribu Bintang. 